\title{
An Investigation into Hybrid Catamaran Fishing Vessel: Combination of Diesel Engine, Sails and Solar Panels
}

\author{
P I Santosa ${ }^{1}$, I K A P Utama ${ }^{1}$, W D Aryawan ${ }^{1}$, D B Purwanto ${ }^{1}$, R-M Chao ${ }^{2}$, and A Nasirudin ${ }^{1,2}$
}

\begin{abstract}
The application of hybrid technology for sea transportation in a way to reduce the use of fossil fuels and the effect of toxic gases into the atmosphere. In more details, the hybrid technology applies two sources or more of energy, namely conventional engine together with the consumption of fossil fuels, use of sail and solar cell panels in conjunction with the use of battery to store the energy gain. The attractiveness and successful application of catamaran form for passenger vessels has inspired naval architect to use it as fishing vessels due to its advantages such as having better transverse stability and providing wider deck-space area. The investigation was carried out both experimentally and numerically. Optimum geometry or ship hull is $L O A=12.9 m, L B P=11.85 m, B=4.0 m, H=1.5 m, T=0.93 m$, selected from previous work. It is then followed by the selection of power combination and model testing and evaluation. The current work describes the development of hybrid technology for a catamaran fishing vessel using the combination of conventional diesel engine, the use of sail and solar-cell panels. The models were tested at speed equal to speed of real vessel at open sea from about 10 knots and the Froude numbers were about 0.48 obtained resistance value about 5,28kN and giving the effective power $(P E)$ about $40 \mathrm{~kW}$. Finally, discovered the combination of diesel engine and solar-sails have reached the optimum benefit of the hybrid concept is 40:60 Hybrid ratio. It's similar to use 16 $k W M / E$ and $252 @ 180 w p$ Solar panels placed on $50 \mathrm{~m} 2$ canopy areas, $110 \mathrm{~m}^{2}$ sail areas and 0.504 ton weight can saving 6 liter/h and reduce the effect of toxic gases into the atmosphere. Stability and sea keeping of boat is good.
\end{abstract}

Keywords — catamaran, fishing vessel, hybrid, solar-sail.

\section{INTRODUCTION}

\section{A. Background}

$\mathrm{D}$ evelopment of environmental friendly vessels has become a major issue since the last 10 years. This is due to the scarcity and high cost of fossil foil especially for major fishermen in developing countries such as Indonesia. It was reported that there was a growth of about $6 \%$ on the construction of fishing vessels between 2001 and 2005 in Indonesia [1]. Those vessels used inboard and out-board engines. However, half of those vessels have not been operated again recently attributed to the high cost of fuel oil. Other reason relates to efforts to reduce the spread of toxic gases to the atmosphere such as $\mathrm{CO}, \mathrm{CO} 2, \mathrm{SO} 2$ and $\mathrm{NO}_{2}$ which is mainly caused by the use of fossil fuels [2]. Furthermore, new term called EEDI (energy efficiency design index) has been introduced by the IMO (international maritime organization) in order to measure the level of efficiency of the power and its cause into greenhouse gases impact [3]. It implies that the use of fossil fuels should be reduced into a certain level in order to maintain the environment clear and healthy.

Many efforts have been made to help the fishermen especially in order to reduce the use of fuel oil. Several power systems have been developed such as combination of engine and sail which is later known as sail assisted engine [4]. The powering vessel without using engine and fuel oil has later become more popular considering environmental issues known as green economy concept.

P I Santosa, I K A P Utama, W D Aryawan, D B Purwanto, R-M Chao, and A Nasirudin are with Department of Naval Architecture and Shipbuilding Engineering, Faculty of marine Technology, Institut Teknologi Sepuluh Nopember, Surabaya, 60111, Indonesia.

A Nasirudin is with Department of Mechatronics and Marine System Engineering, NCKU, Tainan, TAIWAN.
There are several choices of power systems such as the use of sail, solar powered boat, wave power mechanism and the combination of the two and three power systems. Despite the results of those developments are still far from economic benefits, research and development of those power systems has been carried out very intensive around the world such as reported in [5, 6].

Furthermore, success application of catamaran type of vessel as high-speed passenger carrier has been wellknown and reported in many papers [7-9]. Similar achievements may be applied to the development of fishing vessels, and if it is successful, it can help thousands of Indonesian fishermen to survive as well as to reduce the effect of green-house gas.

\section{B. Formulation and Limitation of Work}

Focus of the proposed research is to investigate the development of catamaran fishing vessel which is powered by hybrid system. The power system may consist of the combination of (1) diesel engine and sail, (2) sail and solar power, (3) diesel engine, sail and solar power, etc.

The study is limited to the use of those power systems in order to produce more efficient and environmental friendly fishing vessels. Combination with diesel engine is taken into consideration because, so far, there is no proven work shows that any alternative power systems can replace the use of diesel engine completely. None of them can provide adequate power compare to diesel engine.

\section{Aims of the Research}

The aims of the proposed research are as follows: (a) Evaluate the best combination of the hybrid power, in particular in term of engineering and economic point of view, (b) Evaluate the ship stability and ship motions of those configurations in order to provide safe and comfortable fishing vessels, (c) Evaluate the EEDI of those configurations as well as the possibility level of green-house gas effect. 


\section{Relevance}

The proposed research is very useful in term of finding alternative power either to replace or complement the use of conventional diesel engine. The combination of those possible powers with diesel engine can reduce fuel consumption and emissions hence safe a lot of money for energy use as well as maintain the cleanliness of the environment.

In more specific context, the work is worthwhile for fishing industry where in particular many Indonesian fishermen cannot afford to purchase fuel oil hence many fishing boats must be grounded. Thus, the majority of fishermen cannot earn money to support their life. If not solved, in one hand, this can increase the number of poverty people in Indonesia. In the other hand, this can increase the level of criminality hence causing communities life unsafe and uncomfortable.

\section{METHOD}

The investigation was carried out both experimentally and numerically. Optimum geometry or ship hull is selected from previous work such as given in [14]. It is then followed by the selection of power combination and model testing and evaluation.

Analysis include the aspects of stability, sea keeping, layout arrangement and economic viability of the development of catamaran fishing vessel.

Measurement the level of efficiency of the power and its cause into greenhouse gases impact [3]. It implies that the use of fossil fuels should be reduced into a certain level in order to maintain the environment clear and healthy.

\section{RESULT AND DISCUSSION}

\section{A. Selection of Power Combination}

The calculation of power required by the catamarans needs an investigation into the resistance characteristics entirely in order to obtain the most by ship design [7, 10]. The resistance of catamaran can provide complex phenomena to ship designers particularly with the appearance of interaction between the semihull of catamaran. Therefore, it has been a basic need to obtain the breakdown and understanding of correct ship resistance components in order to obtain accurate calculation based on scaling transformation from model to the real ship.

A systematic investigation has been made by Insel and Molland [4] showing that there is a certain separation between 2 demihulls causing very small interaction or in practice it can be said that there is no interaction [4]. The small interaction occurs at separation to length ratio $(\mathrm{S} / \mathrm{L})$ of 0.4 and 0.5 and this provides an idea that a catamaran with similar displacement comparable to monohull could have smaller or equal resistance and hence power of main engine.

The most widely used estimation of catamaran resistance is the method proposed by Insel and Molland [14]. In this case, catamaran hull consists of 2 isolated demihulls and creates wave and viscous resistance interference and formulated as follows:

$C_{T}=(1+\phi k) \sigma C_{F}+\tau C_{W}$

Where:

$\mathrm{CT}$ is total resistance coefficient,
$\mathrm{CF}$ is frictional resistance coefficient and obtained from ITTC-1957 correlation line, CW is wave resistance coefficient of isolated demihull, $(1+\mathrm{k})$ is form factor value of isolated semihull, $\varnothing$ is used to estimate the change of pressure around demihull, $\sigma$ represents additional velocity between demihulls and calculated from the summation of local frictional resistance around wetted surface area.

In fact, the factors of $\varnothing$ and $\sigma$ are difficult to measure hence for the practical purposes, the two factors can be combined to form viscous resistance interference factor $\beta$ where hence:

$$
C_{T}=(1+\beta k) C_{F}+\tau C_{W}
$$

Where for monohull or demihull at isolation the value of $\beta=1$ and $\tau=1$.

Experimental Investigation

The experimental work was conducted using towing tank and a symmetrical catamaran model $(\mathrm{S} / \mathrm{L}=0.4)$ were tested (see Figure 1). The models were tested at speed equal to speed of real vessel at open sea from about 5 to 10 knots and the Froude numbers were about 0.24 to 0.48 or from low speed to medium speed condition [9]. Principal particulars of the ship is given in Table 1 . The model is made from FRP in order to obtain appropriate displacement as scaled from full ship mode in accordance with Froude law of similarity. Table 2 indicate that the resistance is affected by the change of hull clearance $(\mathrm{S} / \mathrm{L})$ for symmetrical catamarans. Figure 2 shown that the smaller the clearance $(\mathrm{S} / \mathrm{L})$, the higher the resistance and the critical Froude number becomes. The small interactions occur at clearance ratio $(\mathrm{S} / \mathrm{L})$ of 0.4 and this provides an idea that a catamaran with similar displacement to comparable monohull could have smaller resistance and power of main engine. As a result, predictions on resistance are good way to know how the energy is spent.

\section{B. Numerically Analysis}

The numerical work was carried out using commercial design software (Maxsurf and Ansys CFX). The CFD code of ANSYS - CFX adopts a false time step or pseudo-time step to solve equations as a means of under relaxation. The under relaxation is necessary to stabilize some iterative processes of obtaining steady state solutions [15]. The separation to length $(\mathrm{S} / \mathrm{L})$ ratio was taken as 0.2 only.

Figure 3 shows the resistance comparison of experiment and CFD simulation for symmetrical and asymmetrical catamaran with clearance ratio $\mathrm{S} / \mathrm{L}=0.2$. It is found that the resistance for asymmetrical catamaran is higher than that for symmetrical one.

In general, the resistance results of Numerical calculation (CFD) show higher than that of experimental work. The magnitude of Resistance is $5.28 \mathrm{KN}$ as experiment result for use calculated power of boat. Furthermore, the effective power of the boat is calculated using Equation (3) and giving the effective power (PE) about $40 \mathrm{~kW}$. However, since the boat is a catamaran and using two engines and propellers hence the capacity of each engine is $20 \mathrm{~kW}$. The thrust power is calculated using Equation (3) and giving thrust power ( $\mathrm{T}$ ) of about $40 \mathrm{~kW}$.

$P_{E}=R_{T} V$ 
The boat required 252 solar panels in which each panel can produce energy about 180 WP (watt-peak). The charged battery can power the boat, solely supported by 252 solar panels, with $262 \mathrm{~m}^{2}$ areas and 0.504 Ton weight. Sail areas $=125 \mathrm{~m}^{2}$ with ratio $(\mathrm{SA} / / \mathrm{WSA})=$ 2.55, [20].

Layout Arrangement of catamaran type of vessel is presented in Figure 4(a). The layout shows the arrangement of fish holds and area for crew activities on the main deck. Figure 4(b) shown the 3D model of Hybrid Catfish Vessel.

The wider space area for fishing activities on main deck is the main concern for the commercial fishing industry now. The space area on main deck for catamaran is mostly related to the separation length ratio $(\mathrm{S} / \mathrm{L})$. Therefore this ratio need to be investigated and discussed into the resistance performance to estimate the ship speed and powered required. The large, which provides an incredible amount of spaces for accommodation, engine room and massive fish storage. The Data of catfish vessel is LOA $12.90 \mathrm{~m}$, LPP 11.85 m, H $0.50 \mathrm{~m}$, B 4.0m, Bdemihull $1.4 \mathrm{~m}$, T $0.93 \mathrm{~m}, \mathrm{CP}$ 0.60, CM 0.785, CW 0.71, S/L 0.40, Displ 15.086T, LWT 5.709 T, Payload 3.2 GT, X Main Engine $20 \mathrm{~kW}$, Solar Panel 252pcs @180 WP, Sail areas $125 \mathrm{~m}^{2}$, Hybrid Ratio 40:60. Solar panels were used to absorb energy from sun-rays and then saved it into battery. This mechanism was managed by a battery recharge controller circuit is presented in Figure. 5. The controller maintains the battery voltage of about $24 \mathrm{~V}$. If the voltage drops until $22.2 \mathrm{~V}$ then the controller will charge the battery using energy from solar-cell panel automatically. The controller will stop recharging process when the voltage arrives at 26.3V [1].

\section{Stability and Sea keeping}

Ship stability is an area of naval architecture that deals with how a ship behaves at sea, both in still water and in waves. Stability calculations focus on the center of gravity and center of buoyancy of vessels and how these interact. When a ship hull is designed, stability calculations are performed for the intact and damaged states of the vessel [13]. Intact stability calculations are relatively straightforward and involve taking all the centers of mass of objects on the vessel and the center of buoyancy of the hull. Cargo arrangements and loadings, crane operations, and the design sea states are usually taken into consideration. Meanwhile, damage stability calculations are much more complicated than intact stability. Finite element analysis is often employed because the areas and volumes can quickly become tedious and long to compute using other methods. Among others, catamaran or twin-hull vessel has better transverse stability compared to monohull vessel. This is one of the main reason why catamaran becomes more popular compared to other types of vessel. This vessel type has been applied successfully as passenger carriers, oceanographic research vessels, and leisure boats [8]. Recent work shows that catamaran is feasible as fishing vessel, particularly for coastal waters operation as reported [14]. Sea keeping ability is a measure of how well-suited a watercraft is to conditions when underway [24]. A ship or boat has good sea keeping ability is said to be very seaworthy and is able to operate effectively even in high sea states. [25]
Suggested four principal terms needed to describe a sea keeping performance and these include the mission of ship, environmental conditions, ship responses, and sea keeping performance criteria. It is obviously that a passenger ship and a fishing vessel have different missions and operate in different environments. The performance criteria will be different as well. Both may be considered seaworthy, although for different reasons based on different criteria. Furthermore, sea keeping directly impacts the design of a vessel. Ship motions are considered when determining the principal dimensions of the ship and in developing the general arrangements of the ship's internal spaces. For example, in most vessels the far forward parts of the ship experience the worst ship motions and are commonly un-acceptable for berthing passengers or crew.

Overall, ship stability and sea keeping evaluation are considered for fishing vessels because of the placement of sail and (later) solar panel can reduce the ship stability and sea keeping qualities. Also, fishing vessels are usually operated in more open sea hence this vessels are prone to capsize. In this case, for additional of weight about 0.504 tons does not affect to the ship stability and sea keeping qualities.

Several surveys indicated that fishing vessel has reached the highest accident rates among other types of vessel [13]. Dynamic stability analysis, which is known as sea keeping, has been carried out in [9] which demonstrated that the catamaran mode shows almost similar motion characteristics as compared to the monohull type. This is true for sea state up to 3 which then indicated that catamaran is as comfortable as the monuhull. In detail, it was reported that heave and pitch motions of catamaran are more excessive under following sea condition (see Figures 7 and 8), whereas the roll motion is more extreme under quartering and beam sea conditions. The responses of roll motions of catamaran was given in Fig. 9 indicating that catamaran has slightly better rolling motion that than of the monohull. It implies that catamaran is, in fact, slightly more comfortable than the monohull.

\section{Measuring of Emission}

International Maritime Organization (IMO) adopted a new chapter to MARPOL annex VI in order to reduce GHG emission from international shipping by improving the energy efficiency for ships. The hull design, propulsion techniques and operational practices are expected technology that can be improved in order to increase the energy efficiency for ships. The Marine Environment Protection Committee (MEPC) approved the interim guidelines on the method of calculation of Energy Efficiency Design Index (EEDI) towards determining minimum energy efficiency level for new ships. It is mandatory to all merchant ships of $400 \mathrm{GT}$ and above regardless the nationality of the owners [19]. However, it is considered in the near future to apply to other type of vessels using fossil fuels.

Furthermore, the EEDI formula provides a specific for an individual ship design, as proposed by IMO, as given in Equation (4):

$\mathrm{EEDI}=\frac{\mathrm{P} \times \mathrm{sfc} \times \mathrm{C}_{\mathrm{F}}}{\mathrm{C} \times \mathrm{V}} \mathrm{gm} \mathrm{CO}_{2} /$ tonnemile

Where $\mathrm{P}$ is power $(\mathrm{kW})$, sfc is specific fuel consumption $(\mathrm{gm} / \mathrm{kW} \cdot \mathrm{hr}), \mathrm{CF}$ is a $\mathrm{CO} 2$ conversion (tone 
$\mathrm{CO}_{2}$ /ton fuel), $\mathrm{C}$ is the capacity of the ship (DWT or GT) and $\mathrm{V}$ the speed (knots). As such, EEDI can be seen as a measure of a ship's $\mathrm{CO} 2$ efficiency.

When considering the overall form of EEDI, it is clear that in order to reduce the index for a given ship at a given speed, a decrease in propulsive power must be achieved and/or improvements made in engine efficiency with a reduction in sfc. Consideration to small vessel i.e. fishing vessel. In the complete combustion of a so-called $\mathrm{C}_{\mathrm{x}} \mathrm{H}_{\mathrm{y}}$ fuel, consisting only of $\mathrm{C}$ and $\mathrm{H}$ atoms, the exhaust gas contains the components oxygen $\left(\mathrm{O}_{2}\right)$, nitrogen $\left(\mathrm{N}_{2}\right)$, carbon dioxide $(\mathrm{CO} 2)$, and steam $\left(\mathrm{H}_{2} \mathrm{O}\right)$.

In real, incomplete combustion, carbon monoxide (CO), unburned hydrocarbons (HC), nitrogen oxide (NOx), and particulates also appear in addition to the above components. As opposed to these substances, which are detrimental to human health, $\mathrm{CO}_{2}$, which is partially responsible for the greenhouse effect, is not viewed as a pollutant, since it does not pose a direct health hazard and appears as the final product of every complete oxidation of a hydrocarbon. A reduction of $\mathrm{CO}_{2}$ in the exhaust gas is thus only to be achieved through a reduction in consumption or through an altered fuel having a smaller amount of carbon with reference to its heating value. In Figure. 10, the orders of magnitude of the concentrations of various pollutant components in the exhaust gas of an internal combustion engine is given. Different engine construction types as well as gasoline and diesel fuels do not differ as far as the order of magnitude is concerned. The concentrations of all dioxins and furans lie in the order of magnitude of 10-9 $\mathrm{kg}$ per $\mathrm{kg}$ in the exhaust gas and the concentrations of the infamous Seveso poison in the order of magnitude 10-14 $\mathrm{kg}$ per $\mathrm{kg}$ in the exhaust gas, i.e. far beneath the detection margin of present-day measurement techniques [18]. In this case, the boat use hybrid system powered with ratio $40: 60$ and has potency saving 6 liter per hours, is mean can reduce the toxic gasses similar with it.

\section{CONCLUSION}

The current work clearly portraits the study into the development of Hybrid Vessel in order to reduce the use of fossil fuels. It has been found that the use of sail and solar panel in combination with the operation of electric engine was to be very useful.

Economic review indicates the potency of cost saving if the hybrid system (combination electric engine, sail and solar panel) is applied to small boat such as Catfish vessel and could be save about $60 \%$ fuels consumption.

In term energy index, the system can reduce the emission of greenhouses gases. There is shown a good promise that can lead to significant savings in fuel consumption and hence reduce emission of greenhouse gases. However, in reacting to the increase pressure from the environmental viewpoints and with the possibility of future introduction of emissions trading schemes, reduction in power and emissions might be achieved with design changes and fuel saving devices but this may not be the best economic solution.

\section{REFERENCES}

[1] D. Daniel and H. Chandra, "An Investigation into the Application of Solar Cell as Energy Resource to Power Vessel without Fuel,' Final Report of the PKPP Incentive Program (in Indonesian),
2010

[2] A. Al-Harahsheh and R. Shawabkah, " $\mathrm{SO}_{2}$ Removal by Using Jordanian Oil Shale Ash," 27th Oil Shale Symposium, Colorado School of Mines, 15-17 October 2007.

[3] I. K. A. P. Utama and A. F. Molland, "The Powering of Future Ships Taking Into Consideration Economic Viability and Environmental Issues," ICSOT, Ambon, 7-8 November, 2012.

[4] D. Daniel and H. Chandra, "The Evaluation of Solar Power on Sea Trial Results of Catamaran Boat," Jurnal Kelautan Nasional (in Indonesian), 2011.

[5] C. J. Satchwell, "Windship Technology and Its Application to Motor Ships," Transactions RINA, vol. 131, 1989.

[6] A. F. Molland, S. R. Turnock, and D. A. Hudson, "Design Metrics for Evaluating the Propulsive Efficiency of Future Ships," IMDC, Trondheim, Norway, 2009.

[7] E. D. Fry and T. Graul, "Design and Application of Modern High-Speed Catamarans," Marine Technology, vol.9, no.3, pp 345-357. 1972.

[8] I. K. A. P. Utama, "An Investigation into the Viscous Resistance Components of Catamarans," PhD Thesis, University of Southampton, UK, 1999.

[9] Murdijanto, I. K. A. P. Utama, and A. Jamaluddin, "An Investigation into the Resistance/Powering and Seakeeping Characteristics of River Catamaran and Trimaran," Makara Seri Teknologi, vol 15, no. 1, April 2011.

[10]C. A. Marchaj, "Sail Performance, Techniques to Maximize Sail Power," Revised Edition, London: Adlard Coles Nautical, 2003.

[11]"Windtech'85," in International Symposium on Windship Technology, University of Southampton, UK, 1985.

[12] "Electrical Review," vol. 201, no 7, 12 August 1977.

[13]K. J. Rawson and E. C. Tupper, "Basic Ship Theory," vols. 1 and 2, London: Longman, 1994.

[14]D. Setyawan, I. K. A. P. Utama, and A. Jamaluddin, "Development of Catamaran Fishing Vessel," Jurnal IPTEK, Institut Teknologi Sepuluh Nopember, 2010.

[15]A. R. J. M. Lloyd, "Seakeeping: Ship Behaviour in Rough Weather," London, UK: Amazon, 2001.

[16]E. V. Lewis, "Resistance, Propulsion and Vibration, Principles of Naval Architecture (PNA) The Society of Naval Architects and Marine Engineers," vol. 2, 601 Pavonia Avenue, Jersey city, NJ, 1988.

[17]H. Chandra, I. K. A. P. Utama, and D. Daniel, "An Investigation into the Development of Solar Powered Catamaran," Marine Technology Conference (MARTEC), Kuala Terengganu: Malaysia, 20-22 October 2012.

[18] Simulating Combustion, Simulation of combustion and pollutant formation for engine-development@ B. G. Teubner Verlag / GWV Fachverlage GmbH,nWiesbaden,2004.

[19]IMO. Guidelines on the Method of Calculation of the Attained Energy Efficiency Design Index (EEDI) for new ships.resolution of the Marine Protection Environment Committee, MEPC.212(63), 2012.

[20] Francis S.Kinney,'Skene's elements of yacht design," 1977.

[21]Eric W. Sponberg, "The Design Ratio,” 2011.

[22]C. J. Satchwell, "WindshipTechnology and Its Application to Motor Ships," Trans. RINA, vol. 131, 1989.

[23] M. Insel dan A. F. Molland, "An Investigation into the Resistance Components of High Speed Displacement Catamarans," Meeting of the Royal Institution of Naval Architects, 1992.

[24] A. R. J. M. Lloyd, "Seakeeping: Ship Behaviour in Rough Weather," London, UK: Amazon, 2001.

[25]E. V. Lewis, "Resistance, Propulsion and Vibration, Principles of Naval Architecture (PNA) The Society of Naval Architects and Marine Engineers," vol. 2, 601 Pavonia Avenue, Jersey city, NJ, 1988.

[26] "Greenline," The Hybrid Catalogue, 2010

[27]S. H. Ko and R. M. Chao, "Photovoltaic dynamic MPPT on a moving vehicle," Solar Energy, vol. 82, Elsevier, 2012.

[28]P. I. Santosa and I. K. A. P. Utama, "Preliminary study into the development of hybrid catamaran fishing vessel," Proc. Int. Conference on Marine Technology (MARTEC), Kuala Terengganu, Malaysia, 2012.

[29]P. I. Santosa and I. K. A. P. Utama, "Further study into the development of hybrid Catamaran fishing vessel," Oceanic International Seminar, paper, Situbondo, 2013.

[30]P. I. Santosa and I. K. A. P. Utama, "Techno-Economic review of hybrid / electric catamaran fishing vessel," Proc.Quality in Research (QiR). Yogyakarta, 25-28 June. 2013.

[31] I. K. A. P. Utama, P. I. Santosa, R-M. Chao, and A. Nasirudin, "New concept of solar- powered catamaran fishing vessel," APAC Seminar, paper, Bali, 2012. 


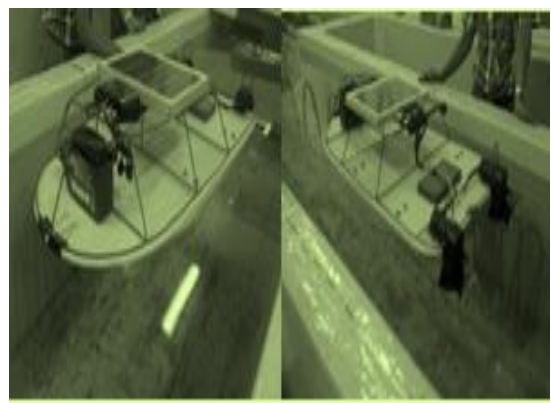

Figure 1. Symmetrical. catamaran $\mathrm{S} / \mathrm{L}=0.4$

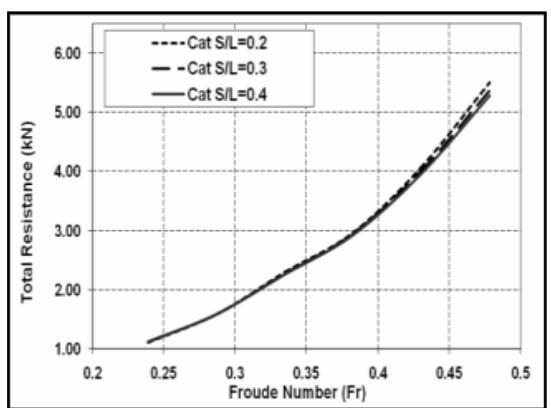

Figure 2. Resistance of symmetrical catamaran

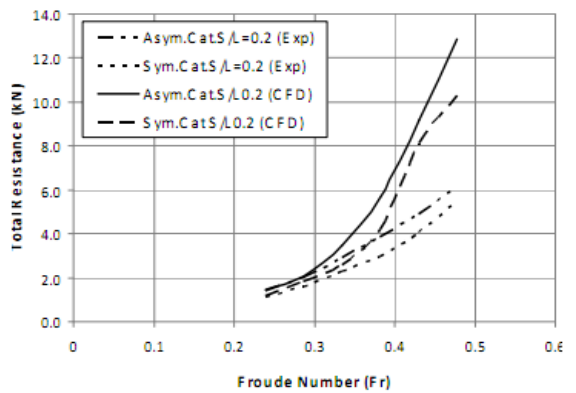

Figure 3. Catamaran resistance of $\mathrm{S} / \mathrm{L}=0.2$ from experiment

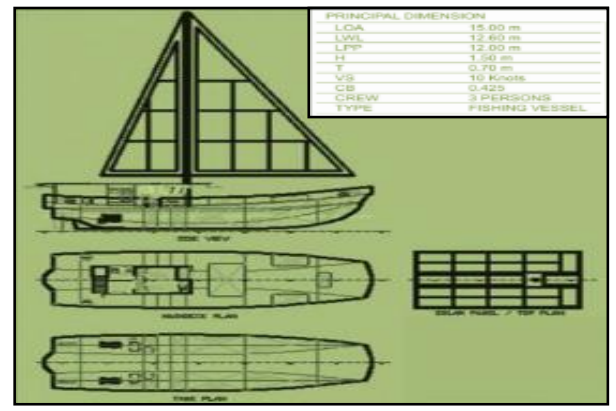

(a) GA

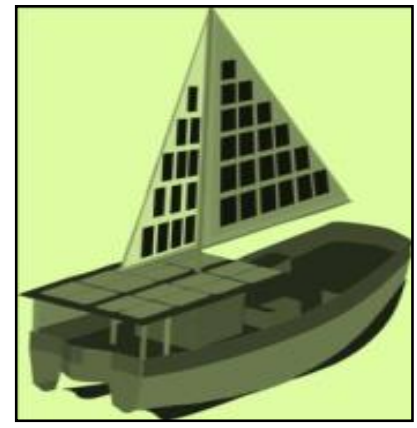

(b) $3 \mathrm{D}$

Figure 4. Layout arrangement of catamaran type of vessel

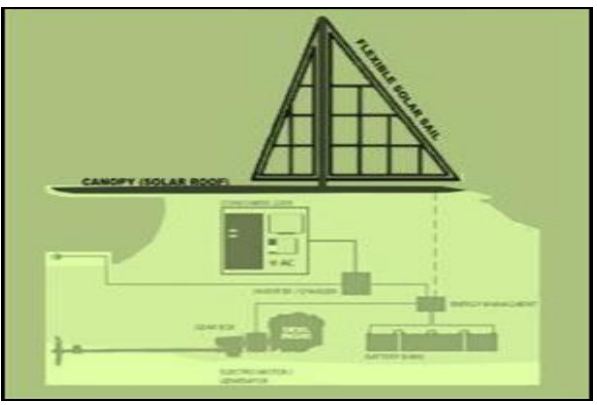

Figure 5. Configuration of hybrid system, [20]

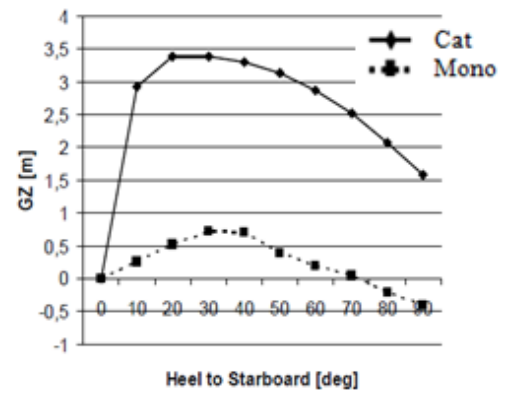

Figure 6. Comparison GZ value, cat vs mono

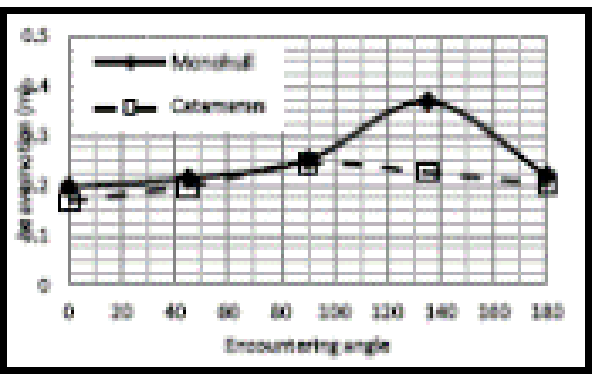

Figure 7. Heave

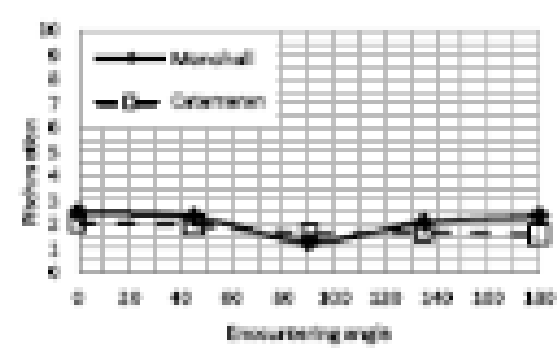

Figure 8. Pitch

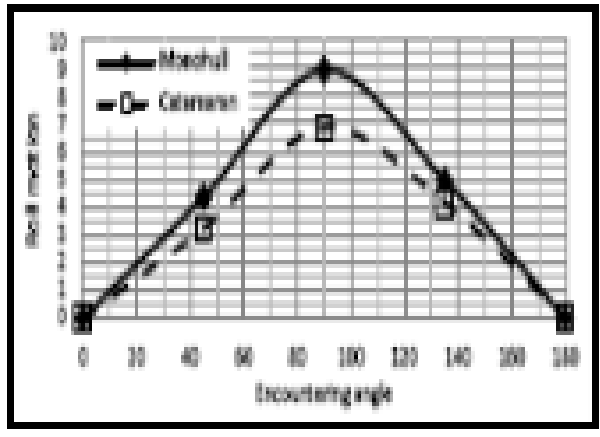

Figure 9. Roll 


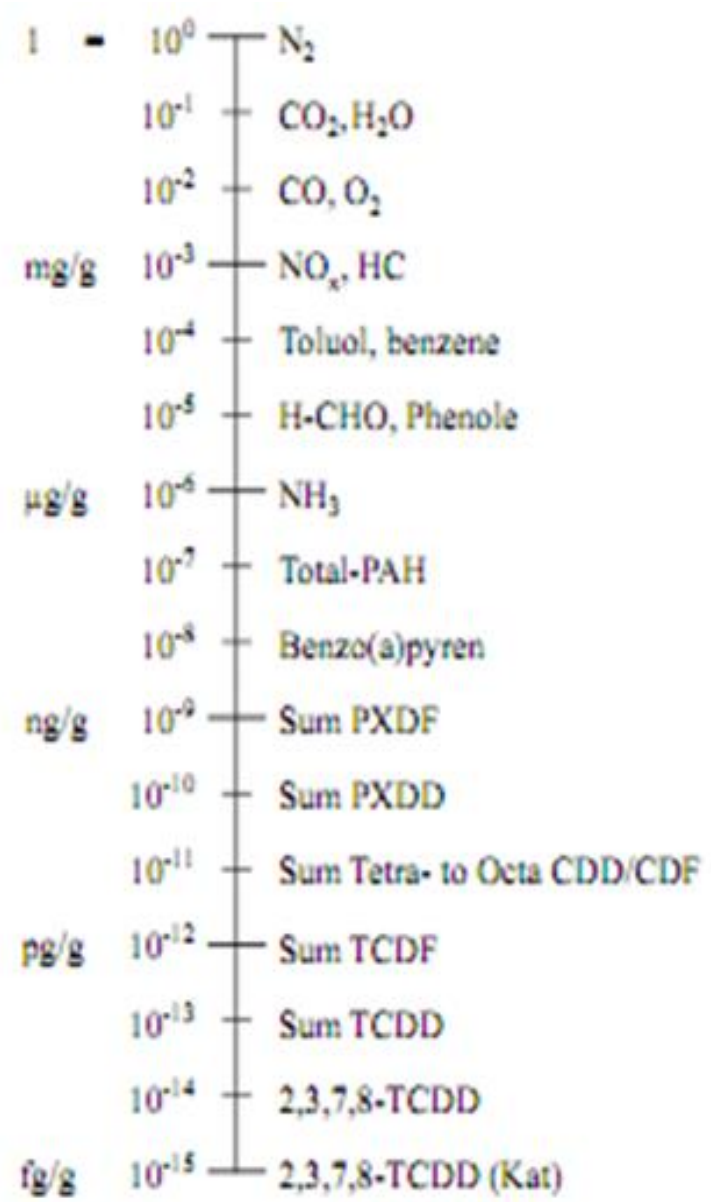

$2,3,7,8 \cdot \mathrm{TCDD}=2,3,7,8 \cdot$ Tetrachlordibenzo-p-dioxin ("Seveso-poison", 1976)

Figure 10. Pollutant concentrations in the exhaust of combustion engines
TABLE 1.

PRINCIPAL PARTICULAR OF SYMMETRICAL CATAMARAN

\begin{tabular}{cccccc}
\hline \hline LOA & LPB & B (m) & H (m) & Vs (knot) & T (m) \\
\hline 12.9 & 11.85 & 4 & 1.5 & 10 & 0.93 \\
\hline \hline
\end{tabular}

TABLE 2.

RESISTANCE OF SYMMETRICAL CATAMARAN

\begin{tabular}{cccccc}
\hline \hline \multirow{2}{*}{$\begin{array}{c}\text { Run } \\
\text { Number }\end{array}$} & Speed & Froude & \multicolumn{3}{c}{ Resistance $(\mathrm{kN})$} \\
\cline { 4 - 6 } & (knots) & Number & $\mathrm{S} / \mathrm{L}=0,2$ & $\mathrm{~S} / \mathrm{L}=0,3$ & $\mathrm{~S} / \mathrm{L}=0,4$ \\
\hline 1 & 5 & 0,239 & 1,11 & 1,12 & 1,12 \\
2 & 6 & 0,287 & 1,59 & 1,59 & 1,59 \\
3 & 7 & 0,335 & 2,3 & 2,28 & 2,26 \\
4 & 8 & 0,382 & 2,96 & 2,94 & 2,92 \\
5 & 9 & 0,43 & 4,06 & 4 & 3,95 \\
6 & 10 & 0,478 & 5,5 & 5,37 & 5,28 \\
\hline \hline
\end{tabular}

TABLE 3.

RESISTANCE RESULT OF CFD ANALYSIS

\begin{tabular}{cccccc}
\hline \hline \multirow{2}{*}{$\begin{array}{c}\text { Speed } \\
\text { (knots) }\end{array}$} & Froude & \multicolumn{4}{c}{ Resistance (kN) } \\
\cline { 3 - 6 } & Number & $\begin{array}{l}\text { Hard } \\
\text { chine }\end{array}$ & $\begin{array}{l}\text { Round } \\
\text { Bilge }\end{array}$ & $\begin{array}{l}\text { Sym. } \\
\text { Cat. }\end{array}$ & Asym. Cat. \\
\hline 5 & 0,239 & 0,55 & 0,45 & 1,19 & 1,47 \\
6 & 0,287 & 0,85 & 0,65 & 1,82 & 2,09 \\
7 & 0,335 & 1,21 & 0,99 & 2,59 & 3,49 \\
8 & 0,382 & 1,63 & 1,34 & 4,20 & 5,65 \\
9 & 0,43 & 2,97 & 3,34 & 8,11 & 9,20 \\
10 & 0,478 & 4,46 & 5,66 & 10,26 & 12,88 \\
\hline \hline
\end{tabular}

